\title{
ENZYMATIC HYDROLYSIS OF BITTER CASSAVA AND GADUNG STARCHES WITH DIFFERENT COMPOSITIONS AT LOW TEMPERATURE
}

\author{
Hargono Hargono ${ }^{1 *}$, Andri Cahyo Kumoro ${ }^{1}$, Bakti Jos ${ }^{1}$ \\ ${ }^{1}$ Department of Chemical Engineering, Faculty of Engineering, Diponegoro University \\ Jl. Prof. Soedarto, SH, Tembalang, Semarang 50275, Indonesia, Telp./Fax.: +62247460058 / +622476480675
}

\begin{abstract}
The effect of compositions of bitter cassava (Manihot glaziovii) and gadung (Dioscorea hispida Dennst) starches on reducing sugar during hydrolysis using granular starch hydrolyzing enzyme (GSHE) was studied. All hydrolyses were conducted at concentration of substrate was 200 g.L. $\mathrm{L}^{-1}$, while concentration of enzyme was $1.5 \%(\mathrm{w} / \mathrm{w})$, during of hydrolysis time $24 \mathrm{~h}$, at $30^{\circ} \mathrm{C}$. Mass compositition of bitter cassava and gadung starches were 9:1 to 1:9 The increase gadung starch compositions will decrease the reducing sugar. The optimum condition of the process using concentration of substrate 200 g. $\mathrm{L}^{-1}$ with compositions of bitter cassava and gadung starches was 9:1 at $18 \mathrm{~h}$. It was found that reducing sugar was 50.20 g.L ${ }^{-1}$. The concentration of reducing sugar mainly depend on starch content on bitter cassava, it is much bigger than the gadung starch.
\end{abstract}

\section{Introduction}

In Indonesia, bitter casava (Manihot glaziovii) and bitter yam (Dioscoreae hispida Dennst) which locally known as gadung are commonly found in secondary forest. They grow under shaded areas or near sreams, not consumed by humans because of the presence of poisonous alkaloids known as cyanogens and dioscorin [1], which can seriously impact the health of the people who consump the tuber. Lambri et al. [2] reported that the total cyanide content of cassava root for sweet white and bitter white were 374 and $442 \mathrm{mg} / \mathrm{kg}$ (d.w), respectively. Djazuli and Bradbury [3] reported of 14 samples of cyanogen content of cassava starch in Indonesia. The maximum value of cyanogens content in cassava starch and cassava flour were $12 \mathrm{ppm}$ and 149 ppm, respectively.

The conventional conversion of starch to glucose requires a two-step process, namely, liquification and saccharification. During liquefaction, gelatination of starch is promoted by applying high temperatute (90-100 $\left.{ }^{\circ} \mathrm{C}\right), \alpha$-amylase is added in order to convert starch into dextrins, maltose and maltotriose. The resulting mash is then cooled to $60{ }^{\circ} \mathrm{C}$ and glucoamylase is added to convert dextrins to fermentable sugars as glucose [4-7]. Granular starch hydrolyzing enzyme (GSHE) is a mixture of $\alpha$-amylase and glucoamylase which hydrolyzes granular starch directly into fermentable sugars and works at low temperature $\left(30\right.$ to $\left.48^{\circ} \mathrm{C}\right)$ and $\mathrm{pH}$ (4.0 to 4.5) [8]. This process is an energy-intensive, and therefore increases the production cost. It has been estimated that about $30-40 \%$ of the total energy is demanded during ethanol production from starch [5]. The use of GSHE presents others advantages, as the GSHE will negate liquefaction and saccharification.
Previous researches were commonly conducted via conventional of hydrolysis and hydrolysis without heating a single substrate, for example the hydrolysis of corn, wheat, tapioca, sago, sorghum starches, etc, only few researches were conducted on hydrolysis enzymatic of double substrate. Uthumporn et al. [9] also reported the hydrolysis of maize, sago and sweet potato starches using $\alpha$-amylase and glucoamylase, at $35^{\circ} \mathrm{C}$ to $50^{\circ} \mathrm{C}$. $\mathrm{Li}$ et al. [10] reported the hydrolysis of corn and triticle starches at $30-50^{\circ} \mathrm{C}$ using $\alpha$-amylase and glucoamylase. Shariffa [11] investigated hydrolysis of tapioca and sweet potato starches by $\alpha$-amylase and glucoamylase, at $35-65^{\circ} \mathrm{C}$.

The objective of this study is to investigate the effect of bitter cassava and gadung starches compositions and on reducing sugar.

\section{Materials and method}

\subsection{Cassava and gadung tubers}

Ten month old of bitter cassava was called Pandemir (Manihot glaziovii) tuber was obtained from Wonogiri district in Indonesia, while gadung tuber with 9 month old was obtained in Godean district in Indonesia.

The extraction method applied to the gadung is the same as the bitter casava extraction method. The method of extraction of the bitter cassava starch, physicochemical properties of the bitter cassava and gadung used in this study were the same as the those used in the previous research conducted by Hargono [12]. Potassium sodium tartrate tetrahydrate and 3,5-Dinitrosalicylic acid, sodium hydroxide $(98 \%$, Merck), sodium sulfite 
(98.5\%, Merck), sulfuric acid (98.5\%, Merck), sodium acetate buffer, glucose (99.5\%), were purchased from their authorized distributor. Granular starch hydrolyzing enzyme as Stargen ${ }^{\mathrm{TM}} 002$, which is a mixture of $\alpha$ amylase and glucoamylase was produced by Genencor (Palo Alto, USA). The activity and optimal $\mathrm{pH}$ range declared by the producer are $570 \mathrm{GAU} / \mathrm{g}$ and 4.0-4.5, respectively [8].

\subsection{Enzymatic hydrolysis}

All hydrolyses were conducted at concentration of starch slurry of 200 g.L. $\mathrm{L}^{-1}$. Mass compositions of bitter cassava and gadung starches were 9:1, 4:1, 2.33:1, 1.5:1, 1.25:1, $1: 1,1: 9,1: 4,1: 2.33$ and 1:1.5. Concentration of Stargen ${ }^{\mathrm{TM}} 002$ was $1.5 \%(\mathrm{w} / \mathrm{w})$ was added into the samples. Samples were then incubated in an incubator shakher at $30 \pm 1^{\circ} \mathrm{C}$, speed of $110 \mathrm{rpm}$. After $24 \mathrm{~h}$, hydrolysis was stopped by adjusting the $\mathrm{pH} 4$ (in $50 \mathrm{mM}$ sodium acetate buffer). Samples were periodically withdrawn from the flask at $6 \mathrm{~h}$ interval and substantially subjected to reducing sugar analysis. Before the samples were analyzed by Spectrophotometer, they were centrifuged $\left(100 \mathrm{~Hz}, 4^{\circ} \mathrm{C}\right.$ and $\left.10 \mathrm{~min}\right)$ to obtain the filtrate. All experiments were performed in triplicates.

\subsection{Analytical methods}

The starch content was determined by AOAC method [13]. The water content in cassava starch was determined by standard drying method in oven at $105^{\circ} \mathrm{C}$ to constant mass [14]. The total cyanide analysis by the acid hydrolysis method [15]. During the cassava starch hydrolysis, the content of reducing sugar was measured using dinitrosalicylic acid method [16]. Reagent consisting of aqueous solution of 1\% 3,5-dinitrosalicylic acid, $0.05 \% \mathrm{Na}$ sulfit, $20 \% \mathrm{Na}-\mathrm{K}$ tartrate and $1 \% \mathrm{NaOH}$ solution was added in the ratio $3: 1$ to the samples in glass tubes, shaken in incubated in a boiling water bath for $8 \mathrm{~min}$. Reacted samples were cooled in an ice water bath for $5 \mathrm{~min}$, prior to measuring absorbance at $540 \mathrm{~nm}$ by using a UV/visible spectrophotometer (UV-160A, SHIMADZU, Kyoto, Japan). Glucose (0 to 60 g. $\left.\mathrm{L}^{-1}\right)$ was used as standard, therefore reducing sugar concentrations was reported as $\mathrm{g} . \mathrm{L}^{-1}$.

\section{Result and discussion}

\subsection{Determination of reducing sugar from bitter cassava and gadung starches hydrolysis}

The reducing sugars obtained from bitter cassava and gadung starches by Stargen ${ }^{\mathrm{TM}} 002$ with concentration $1.5 \%(\mathrm{w} / \mathrm{w})$, and concentration of starch $200 \mathrm{~g} . \mathrm{L}^{-1}$, at $30^{\circ} \mathrm{C}$ and $\mathrm{pH} 4$, during of hydrolysing time 0 to 24 hours are given in Figure 1. Over the hydrolysis time from 0 to $24 \mathrm{~h}$, product of the reducing sugar obtained from of bitter cassava starch was higher than gadung starch.

Production hydrolysis from $0-18 \mathrm{~h}$ showed a maximum reducing sugar concentrations (bitter cassava starch
52.80 g. $\mathrm{L}^{-1}$ and gadung starch 24.65 g. $\mathrm{L}^{-1}$ ), while production rate showed of bitter cassava starch 2.93 g.(Lh) ${ }^{-1}$ and gadung starch 1.37 g.(Lh) ${ }^{-1}$, respectively. Furthermore after 18 hours, the hydrolysis of both of cassava and gadung starches decelerated, and then followed by constant rate to $24 \mathrm{~h}$. The differences of the reducing sugar concentrations, it is because the starch content in gadung is much lower than the bitter cassava starch, as shown in Table 1 and so probably amylose content in bitter cassava starch is much lower than gadung starch. Sharma et al. [17] investigated effect amylose:amylopectin ratios on ethanol production from maize starch using GSHE. They conclused the amylose content in starch increased, the amount of ethanol produced decreased. Wu et al. [18] reported the result showed that the amylose content in starch had a significant effect on the ethanol conversion efficiency. Conversion efficiency increased as the amylose content decreased. So in addition the cyanide content in gadung starch is much higher than bitter cassava starch (Table 1 ), as a consequence the cyanide inhibit the enzyme leading to decrease of enzyme activity.

Table 1. Properties of bitter cassava and gadung starches

\begin{tabular}{|l|c|c|}
\hline \multicolumn{1}{|c|}{ Parameters } & $\begin{array}{c}\text { bitter cassava } \\
\text { starch }\end{array}$ & $\begin{array}{c}\text { gadung } \\
\text { starch }\end{array}$ \\
\hline Moisture content (\%), w/w & 10.80 & 11.12 \\
\hline Starch $(\%), \mathrm{w} / \mathrm{w}$ & 82.70 & 78.85 \\
\hline Cyanide, $\mathrm{mg} / \mathrm{kg}$ & 152.45 & 186.82 \\
\hline
\end{tabular}

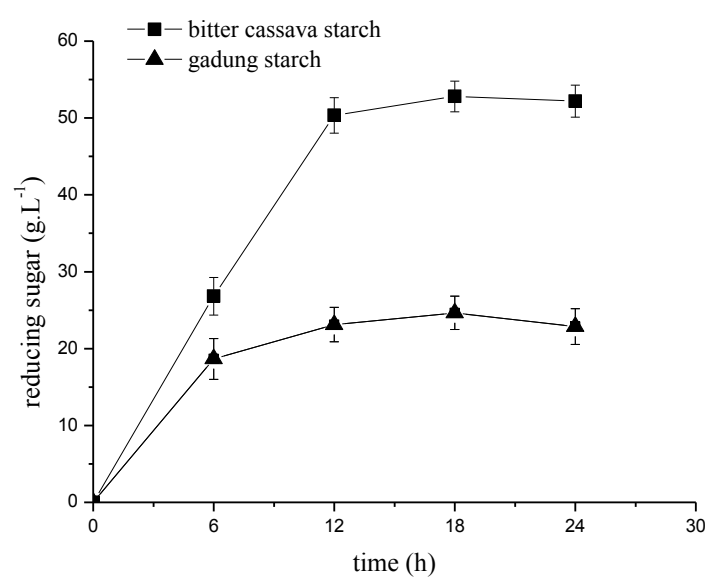

Fig 1. Hydrolysis profile of bitter cassava and gadung starches at concentration of substrate $200 \mathrm{~g} / \mathrm{L}^{-1}$, concentration of Stargen ${ }^{\mathrm{TM}} 0021.5 \%$ (w/w), $\mathrm{pH} 4$ and $30^{\circ} \mathrm{C}$. Each value represents the mean of three independent measurements. Deviation from the mean below $5 \%$ for all values displayed.

Hargono et al. [12] investigated of effect of cyanide on reducing sugar from bitter cassava and gadung flours, we conclused increasing of cyanide concentration during hydrolysis process, decreased enzyme activity, as a consequence amount of reducing sugar decreased. Shanavas et al. [19] reported the reducing sugar formed from cassava starch by varying 
level of Stargen, at $\mathrm{pH} 4.5$ and $30^{\circ} \mathrm{C}$, it was found as $98.3 \mathrm{~g} / \mathrm{L}$ could be hydrolyzed by Stargen level $100 \mathrm{mg}$ on $10 \%(\mathrm{w} / \mathrm{v})$ starch. Also reported by Yussof et al. [20], that the during time 8 to $24 \mathrm{~h}$ hydrolysis native tapioca starch was increasing reducing sugar, as indicated by increasing of dextrose equivalent (DE) 18 to $35.7 \%$.

\subsection{Effect of different composition bitter cassava and gadung starches on reducing sugar}

Figure 2 shows reducing sugar release by enzymatic hydrolysis at a substrate concentration 200 g.L $\mathrm{L}^{-1}$, concentration Stargen ${ }^{\mathrm{TM}} 002$ was $1.5 \%(\mathrm{w} / \mathrm{w}), 30^{\circ} \mathrm{C}$ and $\mathrm{pH} 4$ at various compositions of bitter cassava to gadung starches $(9: 1$ to $1: 1)$ during $24 \mathrm{~h}$. It was found the maximum of concentration of reducing sugars at $18 \mathrm{~h}$ were 50.20 g.L ${ }^{-1},(9: 1), 46.68$ g.L ${ }^{-1}(4: 1), 43.98$ g.L ${ }^{-1}$ (2.33:1), 40.45 g.L $L^{-1}(1.5: 1)$, and 47.49 g.L $L^{-1}(1: 1)$. The production of reducing sugar increased when bitter cassava to gadung starches ratio in the starch composition increased.

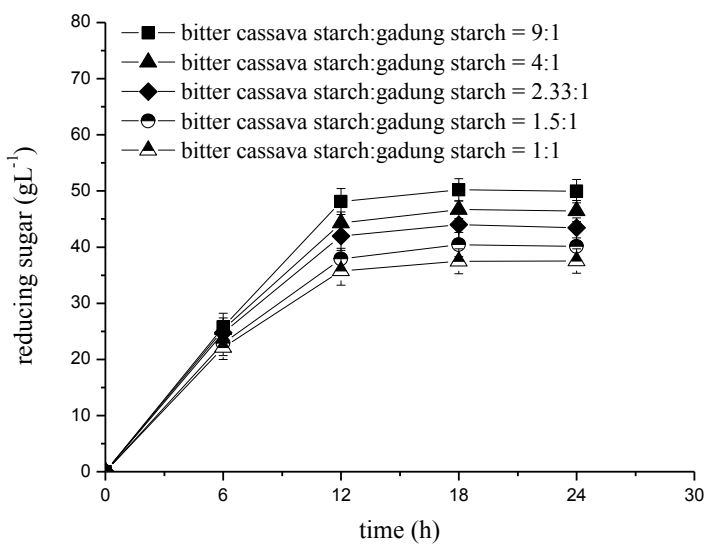

Fig 2. Hydrolysis profile of bitter cassava and gadung starches compositions $(9: 1$ to $1: 1) \mathrm{w} / \mathrm{w}$, at concentration of substrate 200 g. $\mathrm{L}^{-1}$, concentration of Stargen ${ }^{\mathrm{TM}} 002$ $1.5 \%(\mathrm{w} / \mathrm{w}), \mathrm{pH} 4$ and $30^{\circ} \mathrm{C}$. Each value represents the mean of three independent measurements. Deviation from the mean below $5 \%$ for all values displayed.

The result showed that reducing sugar mainly depend on starch content on bitter cassava, it is much bigger than the gadung starch. Thereafter the reducing sugar release by enzymatic hydrolysis at a substrate concentration 200 g. $\mathrm{L}^{-1}$, concentration Stargen ${ }^{\mathrm{TM}} 002$ was $1.5 \%(\mathrm{w} / \mathrm{w}), 30^{\circ} \mathrm{C}$ and $\mathrm{pH} 4$ during $24 \mathrm{~h}$ at various compositions of bitter cassava to gadung starches from $1: 9$ to $2: 3$, as shown in Figure 3. The maximum reducing sugar release at $18 \mathrm{~h}$. It was 27.12 g.L $\mathrm{L}^{-1}(1: 9), 30.12$ g.L 1 , (1:4), 33.14 g.L $\mathrm{L}^{-1}(1: 2.33)$ and 36.08 g.L $\mathrm{L}^{-1}$ (1:1.5). Masiero et al. [21] reported a hydrolysis of fresh potato $\left(200\right.$ g.L $\left.{ }^{-1}\right)$ with Stargen ${ }^{\text {TM }} 002$ (45 GAU.g ${ }^{-1}$ ) during 62 h. After the first $20 \mathrm{~h}$, glucose was liberated 30 g. $\mathrm{L}^{-1}$. Shanavas et al. [18] investigated a hydrolysis of cassava starch $\left(200\right.$ g. $\left.\mathrm{L}^{-1}\right)$, by Stargen ${ }^{\mathrm{TM}} 002$ with concentration $0.4 \%(\mathrm{w} / \mathrm{w})$ at $24 \mathrm{~h}$ and $30^{\circ} \mathrm{C}$, reducing sugar was obtained 185 g.L $\mathrm{L}^{-1}$. The difference in hydrolysis time of our study are much shorter compared to other researchers, because the enzyme concentration is much bigger so that it is more active in degrading starch to reducing sugar.

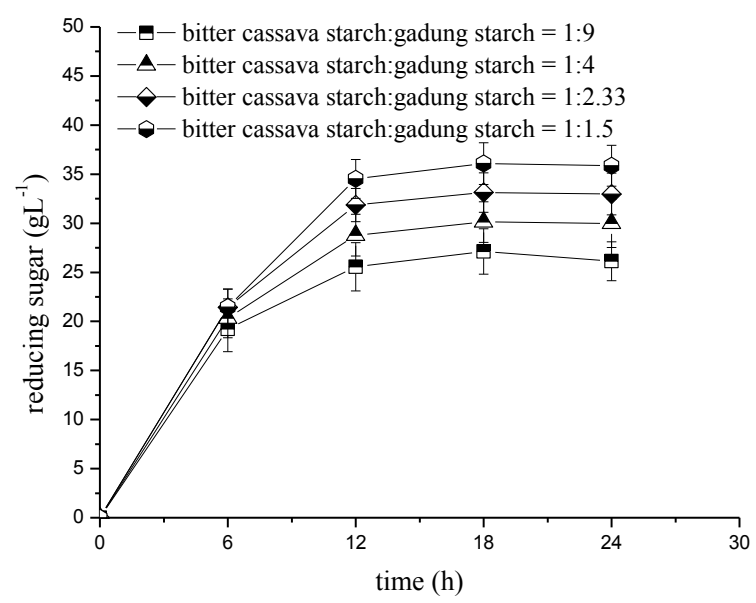

Fig 3. Hydrolysis profile of bitter cassava and gadung starches compositions $(1: 9$ to $1: 1.5) \quad \mathrm{w} / \mathrm{w}$, at concentration of substrate 200 g.L $\mathrm{L}^{-1}$, concentration of Stargen ${ }^{\mathrm{TM}} 0021.5 \%(\mathrm{w} / \mathrm{w}), \mathrm{pH} 4$ and $30^{\circ} \mathrm{C}$. Each value represents the mean of three independent measurements. Deviation from the mean below $5 \%$ for all values displayed

\section{Conclusion}

The experiments conducted an attempt is made to present kinetic expression for the hydrolysis of bitter cassava and gadung starches compositions, at concentration of substrate 200 g. $\mathrm{L}^{-1}$, concentration of Stargen ${ }^{\mathrm{TM}} 0021.5 \%$ (w/w), $\mathrm{pH} 4$ and $30{ }^{\circ} \mathrm{C}$. The results showed that at various compositions of bitter cassava to gadung starches (9:1 to $1: 9$ ) during $24 \mathrm{~h}$. It was found the maximum of concentration of reducing sugars at $18 \mathrm{~h}$ at ratio 9:1 was $50.20 \mathrm{~g} . \mathrm{L}^{-1}$, while the minimum of concentration of reducing sugars at $18 \mathrm{~h}$ at ratio $1: 9$ was 27.12 g. $\mathrm{L}^{-1}$. The release of reducing sugar increased when bitter cassava to gadung starches compositions increased, the concentration of reducing sugar mainly depend on starch content on bitter cassava, it is much bigger than the gadung starch.

\section{References}

1. M. Nashriyah, Y. Nornasuha, T. Salmah, N. Norhayati, M. Rohaizad, (2010 Bulletin UniSZA, 4 (2010)

2. M. Lambri, M.D. Fumi, A.Roda, D.M. Faveri, Afr J Biotechno. 19 (2013)

3. M. Djazuli, J.H. Bradbury, Food Chem. 65 (1999)

4. R.F. Power, The Alcohol Textbook, $4^{\text {th }}$ edition, 23-32, (Nottingham University Press, Nottingham, 2003) 
5. G.H. Robertson, D.W.S., Wong, C.C. Lee, J.Agric. Food. Chem. 54 (2006)

6. E. Sarikaya, T. Higasa, M. Adachi, B. Mikami, Process Biochem. 35 (2005)

7. S. Govindasamy, C.G. H.A. Oates, Carbohydr. Polym. 18 (1992)

8. Genencor (2009) STARGEN тм 002: granular starch hydrolyzing enzyme for ethanol production

9. U. Uthumporn, Y.N. Shariffa, A.A. Karim, Appl. Biochem. Biotechnol. 166 (5) (2012)

10. J. Li, T. Vasanthan, D.C. Bressler, Carbohydr. Polym. 87 (2), (2012)

11. Y.N. Sharrifa, A.A. Karim, A. Fazilah, I.S.M. Zaidul Food Hydrocoll. 23, (2009)

12. H. Hargono, B. Jos, A.C. Kumoro, Bull. Chem. React. Eng. Catal. 12 (2) (2017)

13. AOAC. Official Methods of Analysis of AOAC Intl. $16^{\text {th }}$ ed. Method 991.43. Association of Official Analytical Chemists, Arlington, VA, USA. (1995)

14. B.V. Mc Cleary, V. Solah, T.S. Gibson, J.Sereal Sci. 20 (1994)

15. J.H. Bradbury, S.V. Egan, M.J. Lynch, J. Sci. Food. Agr. 55 (1991)

16. G.L. Miller G.L. Anal.Chem. 31 (1959)

17. V. Sharma, K.D. Rausch, M.E. Tumbleson, V. Singh, Starch/Starke 59 (2007)

18.X. Wu, R. Zhao, D. wang, S.R. Bean, P.A. Seib, M.R. Tuinstra, M. Cambell, A. O Brien, Cereal Chem. 63 (5) (2006)

19. S. Shanavas, G. Padmaja, S.N. Moorthy, M.S. Sajeev, J.T. Sheriff, Biomass and Bioenergy 35 (2) (2010)

20. N.S.Yussof, U.Utra, A.K. Alias, Starch/Starke 65 (2013)

21. S.S. Masiero, A. Peretti, L.F. Trierweiler, J.O. Trierweiler, Biomass and Bioenergy 70 (2014) 